was the only centre in which such an institution would have any chance of success.

At the adjourned meeting, the Dean of Durham and the Rev. Joseph Waite attended on behalf of the University, and as the proposals contained in the Dean's speech on that occasion seem to have been accepted as a general basis for the establishment of the College, we cannot do better than summarise them. They are roughly as follows :-

A College to be established in Newcastle for systematic teaching in Physical Science-literary subjects for the present to form no part of the curriculum.

Four Professorships to be constituted:- $\mathrm{I}$. Pure and Applied Mathematics; 2. Chemistry; 3. Experimental Physics ; 4. Mineralogy and Geology.

The curriculum of instruction to extend over two years; examinations to be held for degrees or diplomas in Physical Science, or other honorary distinctions subsequently determined upon.

Turning to the question of funds-the working expenses, including an adequate provision for the proposed chairs, were estimated at not less than $2,000 l$. per annum, in addition to the amount that might be received from students' fees.

Durham University offered to place in Newcastle two professors-one in Chemistry, the other in Experimental Physics-and to found ten scholarships, each of the value of $20 \%$. per annum : five for first year, five for second year students. This offer was to be understood to extend to six years, but would be made in perpetuity if the results were such as to justify it. The government of the college to rest with a Newcastle board, upon which the University should have representatives. The Professors to be officers in the University, and degrees to be conferred in Durham; the examinations, on the other hand, to be conducted in Newcastle.

The one condition attached to the offer was that Newcastle should find a similar endowment of 1,000 l. per annum, guaranteed for not less than six years.

The meeting appears to have been an eminently practical one, for more than half the required sum was subscribed in the room, and we learn that the amount named has since been considerably exceeded without any active canvass having been resorted to. The offer was naturally considered as accepted, and a Committee appointed to take steps for the carrying out of the scheme. The names of Sir W. G. Armstrong, the Rev. Dr. Lake, Mr. I. Lowthian Bell, Mr. Albany Hancock, and Mr. Newall, in connection with the executive, will carry assurance far beyond the northern counties that whatever is taken in hand will be efficiently accomplished.

The general design, sketched by the Dean of Durhain, is so excellent that we are but little disposed to criticise its individual features, especially as the details which have been made public have not been put forward as representing foregone conclusions, so much as with the intention of supplying a basis for discussion.

If we read the scheme rightly, Durham is to provide two Professors and ten annual 20l. scholarships, and Newcastle to do likewise. Surely twenty scholarships in a newly-established college is an excessive allowance. Possibly this is not intended; at any rate such expenditure of funds would scarcely be entertained by the govern- ing body without some reason not apparent to those less conversant with the requirements of the particular case.

Again, the selection of subjects as laid down by the Dean does not seem to be altogether happy. No scheme of scientific education in the present day can be regarded as satisfactory in which Biological Science is entirely ignored. It is true that the field of biology is too wide to be traversed in detail by a single lecturer or covered by a single course, and were the thing possible it would not be desirable. But it would be perfectly practicable for a Professor in Natural History to give in a short series of lectures much general information as to the organisation of the animal and vegetable kingdoms, and to select some special subject, either zoological or botanical, for more detailed exposition; and, as a means of training the observing powers, no portion of the curriculum would be so valuable. A college devoting its entire energies to one class of natural phenomena, to the exclusion of studies pertaining to natural objects and the phenomena of the organised world, can have no claim to be called a school of physical science in any wide or great sense.

Newcastle has already a position in respect to Natural History Science, and with an admirable Museum at hand, it would be a blot on the undertaking if its abundant local resources were not utilised.

THE UTILISATION OF NATURAL HISTORY MUSEUMS FOR SCIENTIFIC INSTRUCTION IN GERMANY

II.

T HE German Museums of Natural History, founded for educational purposes, and connected with the various Universities, are by far the most important and influential. Those attached to the Universities of Berlin, Vienna, and Munich, are very large establishments, consisting of several sections which are independent of each other; and the aim pursued in each is to render the collections as complete as possible. Hence, although their chief purpose is to serve as schools of instruction for the students, they offer to the specialist abundant materials for original research, and have grown into attractive places of public resort. Those belonging to the smaller Universities are limited to instructive series of types; some, however, excel in one or more special branches. The teachers of the University are always the directors of the collections; thus the Professor of Zoology is the responsible head of the Zoological Museum, the Professor of Mineralogy of the Mineralogical, the Professor of Botany takes the charge of the Botanical Gardens, and so on. The appointments to the professorial chairs are not thrown open to competition ; and the system of testimonials, humiliating alike to the candidate and his supporters, is unknown in German universities; men of repute for their knowledge and capability of teaching are chosen by the Senate, proposed to and appointed by the Government. We believe the Prussian Government has reserved to itself the right of appointment almost independent of the Senate, but, of course, is guided by the advice of men able to judge of the merits of the candidates proposed.

The lectures on the various branches. of Natural History are either given in the Museum itself, or in a place ad- 
jacent. Each course occupies from 50 to roo hours during a term of four months and a haif. Some professors go with their students through a complete course of elementary instruction, whilst others leave this chiefly to private study, devoting the greater part of their time to inducting their pupils into the method of especial research. The attendance of students at the lectures is ensured by the circumstance that the Natural Sciences form part of the objects in which medical men, chemists, and teachers, are examined before they are allowed to enter upon the exercise of their calling. We are informed that, at a University with nearly 700 students (each remaining generally eight terms), some fifty would attend, within one term, the course of Natural Philosophy, or Botany; about twenty-five that of Zoology, or Comparative Anatomy ; from fifteen to twenty that of Mineralogy, or Palæontology; and about thirty-five that of Geology. These were the numbers usually seen in the lecturerooms, but there were, of course, other students who were prevented from attendance by various causes. The majority of those students who are desirous of receiving a perfect scientific education, and have the means for it, take advantage of the great variety of collections and instructors by prosecuting their studies at two or more Universities, fnishing them at those places which offer the largest collections, and, in natural combination, the best instruction.

It may be mentioned here that the teaching of Science in German Universities is not entirely dependent on the public collections. Beside the staff of "ordinary" professors, there are younger men attached to the University, who have the right to teach, but can make only such use of the collections as the ordinary professor is disposed to grant. Most of them select, for their course of lectures, branches in the teaching of which they can dispense with the collections of the Museum-as, physiology of plants, histology and microscopy, history of development, general biology. This institution of "private docents" as they are called, is valuable not only to the students, but also to the body of instructors, inasmuch as it forms a preparatory school for men who intend to undertake the duties of an ordinary University teacher. The presence of an able and popular "private docent" has also not rarely had the beneficial effect of exciting to fresh exertions the ordinary professor, who had gradually lapsed into a course of stereotyped lectures. Nevertheless this institution can be regarded only as supplementary to the system of scientific education which is principally carried out in connection with the Museums.

We are not aware that there has ever been any lack of men combining an exact knowledge of some branch of Natural History with the aptitude for teaching it; nor have we ever heard of complaints that the duties of teaching serionsly interfered with those of the curatorship; on the contrary, their union in one individual can have and has had only a beneficial effect. As teacher he knows best how to regulate the accessions and modify the arrangement of the collection, so as to meet the requirements of, and to be in accordance with, his system of teaching ; and as curator he takes care that those parts which are not in direct connection with the lectures are not neglected, or that valuable specimens are not sacri- ficed for temporary purposes in the lecture-room or student's laboratory. Work in the Museum is as necessary for the training of the students as attendance in the lecture-room; and it is the duty of the teacher to devise suitable objects of research for his pupils. But if he had not the management of the collection, how could he be certain that the materials required are present, or will be made available? Would it be possible for him to superintend the student's work in a place where he is not the master? Were those duties assigned to two individuals, they would soon clash, to the injury of the service expected from the Institution.

The existence of numerous large or well-adapted collections, their utilisation for educational purposes, and the devotion of adequate time to instruction, are among the principal causes which have rendered the system of scientific education successful throughout Germany. But we must not forget that this success is due to the Universities only, and is limited to the classes receiving a University education. In the schools of lower degree, Science (with the exception of chemistry and natural philosophy) is only taught in the form of book-knowledge, in which the pupil takes but little interest, and therefore it has no great or lasting influence on the culture of his mind.

\section{THE DESCENT OF MAN}

The Descent of Man, and Selection in relation to Sex. By Charles Darwin, M.A., F.R.S., \&c. In two volumes. Pp. 428, 475. (Murray, 1871.)

II.

THAT selection in relation to sex has been an important factor in the formation of the present breeds of animals was more than indicated in the "Origin of Species," and the theory has since been especially worked out by Professor Haeckel. It includes two distinct hypotheses. One is that in contests between males, the weakest would go to the wall, and thus either be killed outright, or at least debarred more or less completely from transmitting their characters to another generation. This may be regarded as a particular case of Natural Selection, and may be compared with the theory of protection by mimicry, suggested by Mr. Bates, and carried out by him and by Mr. Wallace. But though in the lists of Love the battle is often to the strong, even more frequently it is to the beautiful. This introduces a new process, of which the effects are not nearly so obvious as those of Natural Selection, either in its simplest form. or in the more complicated cases of mimicry, and of sexual selection by battle. Many circumstances must combine in order that the most successful wooers shall have a larger and more vigorous progeny than the rest. In the first place, all hermaphrodite and all sessile animals may be excluded, and also those cases in which sexual differences depend on different habits of life. Mr. Darwin then shows that secondary sexual characters are eminently variable, and that males vary more than females from the standard of the species, a standard determined by the young, by allied forms, and sometimes by the character of the male himself when his peculiar functions are only periodical, or when they have been artificially prevented. Moreover it is the males who take the active part in pairing, and who not only fight for the possession of their mates, but display their colours, their voice, or whatever 